\title{
EFFECT OF CLASSROOM ELECTRIFICATION ON SCHOOL PERFORMANCE IN CÔTE D'IVOIRE
}

\author{
Tiérégnimin Yaya YÉO \\ $\mathrm{PhD}$ student, University Alassane Ouattara, Bouaké, Côte d'Ivoire, Department of \\ Economic Sciences and Development, Option: Development Economics
}

DOI: 10.46609/IJSSER.2020.v05i03.002 URL: https://doi.org/10.46609/IJSSER.2020.v05i03.002

\begin{abstract}
In recent years, Côte d'Ivoire has adopted national policies to improve household access to electricity. If these policies have increased access to electricity at the household level, it remains very low at the primary school level. To understand the importance of electricity in the school environment, our study aimed to analyse the effect of classroom electrification on school performance. The study uses PASEC survey data from about 2250 students in 150 schools. From the estimation of the multilevel model, it appears that the electrification of classes increases the students' score by 5.9 points. The results also show a positive influence of maternal literacy, the presence of a library, and the possession of textbooks on student performance. However, the student's age and regular housework have a negative influence on student performance on the proficiency tests.
\end{abstract}

Keywords: Electricity, School performance, Multi-level, Côte d'Ivoire, PASEC

\section{INTRODUCTION}

Energy in general, and electricity in particular, is one of the important sources of economic and social development. Access to electricity is crucial for the development of certain basic services such as health, improved agricultural productivity and education. In the field of education, access to electricity can increase learners' study time and promote better retention of educational staff in schools (UNDESA, 2014; UNESCO, 2016). In a world of knowledge transfer, it is clear that electricity is an indispensable element within the education system. It enables the use of modern learning tools in classrooms, such as the Internet, tutorials and devices (UNDESA, 2014).

However, the IEA report (2017) indicates that in 2016, more than 1.1 billion people in the world still had no access to electricity, and the majority of this population lives in the least developed 


\section{International Journal of Social Science and Economic Research}

ISSN: $2455-8834$

Volume: 05, Issue: 03 "March 2020"

countries. Among the regions concerned, sub-Saharan Africa is the most affected by this situation. The Africa's Pulse report (2018) shows, in fact, that sub-Saharan Africa is the region with the lowest household electrification rate in the world, at $42.8 \%$ in 2016. Moreover, studies show that in terms of school electrification, the region records the lowest rate in the world. Only $35 \%$ of primary schools are electrified. This situation makes it difficult to develop and promote education (Provost, 2013). Lack of electricity in schools can have a negative effect on student learning. Information collected from school children in Kenya, Malawi, Tanzania and Zambia revealed that lack of lighting is one of the greatest barriers to learning (YE, 2017). However, some authors argue that lack of classroom lighting hinders learning in Africa. The basic explanation is that light allows teaching early in the morning or late in the evening, thus prolonging learning time. In addition, the presence of electricity in classrooms can lead teachers to work overtime or compensate for the lack of teachers and/or the lack of materials that can facilitate teaching (Kirubi and al, 2009; Davies and al, 2015).

The economic literature assesses the impact of electricity on education through several effects. For some, one of the major impacts of electrification, indeed, is to reduce illiteracy (UNDESA, 2014; Jimirez and Lawand, 2000). When a school is electrified, it facilitates evening classes for adults, thus reducing the illiteracy rate. The study by Diniz and al (2006), reaches the same conclusion. In a study in Brazil, they show that the major impact of school electrification on education is the reduction of illiteracy.

Other studies, on the other hand, have analysed the impact of electricity on school performance. Reference is made to the work of Furukava (2013), Faustino and Medina (2014), UNDESA (2014), Maithani and Gupta (2015). The first study examines the impact of school lamps on students' test results. Using a randomized field experiment, the author shows that the use of school lamps reduces test results by 5 points. However, the study indicates that lamp use is associated with an increase in study time of 30 minutes.

Faustino and Medina (2014) analyze the impact of a school electrification program in the Philippines. In contrast to the results of Furukava (2013), they find a positive and significant influence of the programme on the performance of the beneficiary students. The UNDESA studies (2014) reach the same conclusions. According to the results of this study, in Argentina, staff reported a significant reduction in school absenteeism following the installation of electric lighting. Similarly, in Sudan and Tanzania, access to solar energy resulted in an increase in the primary and secondary completion rate from $50 \%$ to about $100 \%$.

Schools electrification plays a crucial role in improving students' skills through the use of communication and information technologies (Mingaine, 2013). According to the author, the use of ICT can reduce the costs of education and increase its efficiency. In the same vein, Díaz 


\section{International Journal of Social Science and Economic Research}

ISSN: $2455-8834$

Volume: 05, Issue: 03 "March 2020"

(2015) shows that the use of computers has a positive impact on learning when they are specifically adapted and used to teach mathematics, science and technology. Indeed, an impact evaluation of a digitally oriented curriculum in Chile showed that Grade 6 students who benefited from the programme experienced a 10 percentage point increase in their exam scores in science and English. In addition, Maithani and Gupta (2015) found that schools in rural India are often poor because lack of lighting in classrooms prevents children from reading or writing.

Study time is an essential element in the acquisition of knowledge. Indeed, to better assimilate learning and benefit from its added value, students need time to learn. Thus, some authors show empirically the importance of access to electricity through the improvement of study time. Aguirre (2017) analyses the impact of rural electrification on education in Peru. Using the ordinary double least squares method, the results show that children whose families are connected to the electricity grid increased their study time. This increase in study time varies on average between 94 and 137 minutes per day.

Kumar and Rauniyar (2018) achieve similar results. These authors examine the impact of a rural electrification programme on household income and children's schooling. The evaluation method is propensity score evaluation. The results reveal a statistically significant impact of electrification on children's income and education. Indeed, the electrification programme has led to a $61 \%$ increase in non-agricultural income. Similarly, the average number of years of schooling and the time spent in school increased by 0.72 years and 9 minutes respectively.

Similar studies have been carried out in Bangladesh and Vietnam (Klandker et al 2012; 2013). The 2012 study in Bangladesh indicates a positive and significant impact on study time, as access to electricity resulted in an increase in study time of 22 and 12 minutes for boys and girls respectively. In Vietnam, the authors find that household access to electricity increases the average number of years of schooling for boys by 0.11 years. However, this effect is insignificant for girls.

Another contribution that analyzes the impact of electricity on study time from a gender perspective is that of Barron and Torero (2014). These authors analyze the impact of random assignment of connection vouchers on home study time in El Salvador. The regression of a panel model by instrumental variables shows that electrification increases the probability of studying at home by $54 \%$ and the probability of participating in other school-related activities by $84 \%$. Their study also shows that the implementation of the program resulted in an increase of about 10 minutes in total study time per day for both boys and girls. Van de Walle et al $(2013 ; 2017)$ achieve the same results when they examine the long-term effect of a programme to roll out the electricity grid in India. They use the double difference method to analyse the impact of 


\section{International Journal of Social Science and Economic Research}

ISSN: $2455-8834$

Volume: 05, Issue: 03 "March 2020"

household electrification on consumption, employment and school enrolment. The study covers the period 1982 - 1999.

As can be seen, several studies highlight the positive impact of household or school electrification on education. Wider access to electricity in schools is expected to increase student access and retention. However, against all expectations, the study by Squires (2015) showed that access to electricity reduces the level of schooling during a programme of electricity expansion in Honduras. However, this reduction was accompanied by an improvement in the employment rate.

As it appears, it seems to be difficult to establish empirically a clear relationship between access to electricity and the increase in schooling (average number of years of schooling). It is therefore appropriate to ask the following question: Does access to electricity really contribute to the development of education?

This question shows that reflections on the issue are far from over; it opens up avenues for research on the link both theoretically and empirically. Moreover, although recent studies highlight the impact of electrification on schooling in developing countries, most of them are carried out in the countries of Aise and Latin America. The empirical literature on the issue remains generally weak in Africa. This article is therefore intended as a contribution to the literature on this issue and seeks to analyse the effect of electricity on school achievements in Côte d'Ivoire.

The further work is structured as follows: Section 2 presents the situation of access to electricity in Côte d'Ivoire; section 3 describes the data and the econometric methodology used; section 4 is devoted to the estimation and discussion of the results and finally the conclusion is made in section 5 .

\section{ACCESS SITUATION TO ELECTRICITY AND EDUCATIONAL ACHIEVEMENTS IN CÔTE D'IVOIRE}

Sub-Saharan Africa remains the region where the rate of access to electricity is still low. More than 590 million people (about $57 \%$ of the population) still do not have access to electricity (IEA, 2017). However, according to an IEA report (2017), the number of people without access to electricity has stopped increasing since 2013. This decline is the result of efforts made by some countries in the region ${ }^{1}$.

\footnotetext{
1 The International Energy Agency (IEA) report, published in 2017, says the number of people without access to electricity has declined as a result of major efforts in Côte d'Ivoire, Ethiopia, Ghana, Kenya, Sudan and Tanzania. Thus, since 2012, the rate of electrification has almost tripled compared to the 2000-2012 period.
} 
International Journal of Social Science and Economic Research

ISSN: $2455-8834$

Volume: 05, Issue: 03 "March 2020"

For its part, Côte d'Ivoire has made progress in recent years in terms of access to electricity. Thus, the access rate rose from $51.4 \%$ in 2002 to $64.3 \%$ in $2016^{2}$. However, there are great disparities between rural and urban areas. In 2015, only $28.7 \%$ of the rural population had access to electricity compared to $70.3 \%$ in urban areas (INS, ENV 2015). With regard to primary schools, which are mostly in rural and peri-urban areas, there is a serious problem of access to energy services. In total, in 2012, only $25 \%$ of primary schools have electricity, with $9 \%$ in rural areas against 55\% in urban areas (UNDP, 2012). Four years later, this proportion has slightly increased. Thus, in 2016, the total proportion of electrified primary schools rose to 30\% (DSPS Report, 2017). However, the disparity between urban and rural areas persists. Indeed, in 2016, the number of electrified primary schools in rural areas is estimated at $11 \%$ against $66 \%$ for those located in urban areas. At the level of secondary schools, the situation has clearly improved. According to the DSPS report (2017), 79\% of general secondary schools have access to electricity. The various statistics show that Côte d'Ivoire needs to make enormous efforts in terms of access to electricity in primary schools.

The literature has mentioned the positive impact of school electrification on education indicators and on teachers' living conditions. The low level of school electrification observed leads us to take stock of certain education indicators in Côte d'Ivoire. According to World Bank data, in 2017, more than $35 \%$ of primary school pupils did not manage to complete the primary cycle (WDI, 2016). As for the other levels of education, the enrolment rate is still very low (43.28\% in secondary and $9 \%$ in higher education). When considering educational achievements, the situation is even more worrying. According to the most recent evaluation of the CONFEMEN Programme d'Analyse des Systèmes Educatifs (PASEC), in Côte d'Ivoire only 17.3\% of primary school pupils reach the sufficient threshold of reading competence. In mathematics, the rate is $33.8 \%$. This means that the others were not able to read a word in a sentence or solve a small mathematical problem.

\section{STUDY METHODOLOGY AND DATA}

This section presents the econometric method used, the nature of the data used and a description of the various variables.

\subsection{Methodology}

We analyze the effects of school electrification on the educational performance of students. As mentioned earlier, our data have a hierarchical structure. Given this structure, ordinary least squares (OLS) techniques are no longer efficient. Indeed, mixing several levels of analysis in the same research model poses enormous problems. This requires the use of an analytical method

${ }^{2}$ According to the World Bank database (Last updated, 2018). 
International Journal of Social Science and Economic Research

ISSN: $2455-8834$

Volume: 05, Issue: 03 "March 2020"

that can solve this problem by taking into account the "levels" dimension in the analyses. The hierarchical linear model makes it possible to work efficiently on these types of data. A researcher using this model must therefore consider interactions between variables at different levels.

These models apply well to situations where individuals share a common environment that may affect the phenomenon of interest (Givord and Guillerm, 2016). Consider, for example, the situation of students in a class. Their individual characteristics can determine their level of acquisition. But beyond these characteristics, the fact that they benefit from the same teaching conditions can also influence their academic achievement. The same applies to the motivation of employees in the same company, to the inhabitants of the same neighbourhood, etc. The same is true for the motivation of employees in the same company, for the inhabitants of the same neighbourhood, etc. The model used in this work is inspired by Bressoux (2010) and Givord and Guillerm (2016).

We begin by writing the equation using only the variables at the most disaggregated level, i.e. level 1 (student level). Thus, the structure of the two-level multilevel model for student $i$ of school $\mathrm{j}$ is written:

$$
Y_{i j}=\beta_{0 j}+\beta_{1 j} X_{i j}+\varepsilon_{i j}
$$

Where $\mathrm{i}$ is the student index and $\mathrm{j}$ is the school index, $\mathrm{X}$ is a set of level 1 variables, $\beta_{0 j}$ is a constant, $\beta_{l j}$ is a parameter to be estimated and the error term.

The interest of the multilevel model being to allow the hierarchical structure of the data to be taken into account, we then introduce into the model the variables relating to level 2. Suppose $\mathrm{Z}$ is the set of these variables. These level 2 variables are used to explain the variations of the level 1 parameters. At level 2 the model can therefore be written as follows:

$$
\begin{aligned}
& \beta_{0 j}=\gamma_{00}+\gamma_{01} Z_{j}+u_{0 j} \\
& \beta_{1 j}=\gamma_{10}+\gamma_{11} Z_{j}+u_{1 j}
\end{aligned}
$$

The error terms, $\varepsilon_{i j}, u_{0 j}$ et $u_{1 j}$ are all randomly distributed with a mean of zero. However, error terms at the same level follow a multivariate normal distribution. The errors in general are heteroskedastic and correlated with each other. However, from one level to another, they are assumed to be uncorrelated. 
Integrating equations (2) and (3) into equation (1) gives:

$$
Y_{i j}=\gamma_{00}+\gamma_{01} Z_{j}+\gamma_{10} X_{i j}+\gamma_{11} Z_{j} X_{i j}+u_{0 j}+u_{1 j} X_{i j}+\varepsilon_{i j}
$$

The resulting equation (11) expresses student learning in terms of explanatory variables at all levels. In this equation, the term $\gamma_{00}+\gamma_{01} Z_{j}+\gamma_{10} X_{i j}+\gamma_{11} Z_{j} X_{i j}$ represents the fixed effects of the model. The second term is the random part with $\varepsilon_{i j}$ for level $1, \mathrm{u}_{0 \mathrm{j}}+\mathrm{u}_{1 \mathrm{j}} \mathrm{X}_{\mathrm{ij}}$ for level 2 .

Compared to classical models with OLS techniques, two fundamental differences are observed in this multi-level model. The first is the appearance of an interaction term between the explanatory variables $\left(Z_{j} X_{i j}\right)$. This interaction between the explanatory variables appears not only in the fixed part but also in the random part of the model. The second difference observed is the appearance of complex relationships between the different levels of the model, at the level of the explanatory variables and also between the error terms and the explanatory variables of the model.

\subsection{Data}

To analyze the effect of electricity on school performance, we use survey data from CONFEMEN's Programme d'Analyse des Systèmes Educatifs (PASEC) ${ }^{3}$. The data used are collected in 2008. The objective of PASEC is to provide a measure of educational achievement at the beginning and end of the year. To this end, French and mathematics tests are administered to pupils in the 2nd and 5th years of primary school. The 2009 sample included approximately 2250 students from 150 schools. In order to collect information about students and their schools, PASEC administers contextual questionnaires to students, teachers and principals. In order to improve the representativeness of the sample, PASEC uses stratified samples to draw schools. This sampling technique is used in order to cover as much as possible the different realities of a country's education system. The number of schools sampled in a stratum is directly proportional to the total number of 2nd and 5th grade classes in that stratum (PASEC Report, 2012). Thus, the probability that a school belongs to the sample is a function of the total number of 2 nd and 5 th year classes within this school.

\subsection{Variable description and descriptive statistics}

The choice of variables is largely based on the literature review. The variable to be explained in this research is obtained from the scores obtained in reading and mathematics (PASEC Report,

\footnotetext{
${ }^{3}$ PASEC, created in 1991, is a programme that implements evaluations aimed at reporting on the performance of the education systems of the member countries of CONFEMEN (the Conference of Ministers of Education sharing the French language), 


\section{International Journal of Social Science and Economic Research}

ISSN: $2455-8834$

Volume: 05, Issue: 03 "March 2020"

2012). It refers to a student's performance on the proficiency test. Scores are calculated by summing the correct answers in each discipline. Missing answers are considered incorrect answers. Each correct answer is equal to 1 and each incorrect answer is equal to 0 . Thus, the scores are reported out of 100 and become the percentages of correct answers. In order to obtain an average score we calculate the average of the scores of the two disciplines. This variable is called "Score_Elev".

It should be noted that we only consider the results of students at the end of their schooling, i.e. those of the 5th year. Indeed, in most cases, teachers at the primary level vary from one year to the next. Children can also change schools. Thus, if we integrate the results of pupils at the beginning of schooling (2nd year of schooling), there is a strong chance that this variable absorbs part of the characteristics of the pupil and his family. This is because the characteristics of the student and his or her family simultaneously determine the results at the beginning and end of schooling (Michaelowa, 2000).

Explanatory variables are considered at different levels. Thus, for the choice of variables, we used the PASEC survey questionnaire. The "student" questionnaire provided the information on the level 1 variables. Level 1 (student level) provides information on the student's individual characteristics, family background, school resources and well-being at school. For level 2 (school level), the questionnaires addressed to the students' teachers provide information on their individual characteristics, their academic and professional training, their status and remuneration. Similarly, they provide information on the characteristics of the class surveyed, teaching, meetings and supervision, working conditions, classroom infrastructure and equipment.

Names and descriptions of all selected explanatory variables are given in Table (1) below. 
International Journal of Social Science and Economic Research

ISSN: 2455-8834

Volume: 05, Issue: 03 "March 2020"

Table 1: Description of explanatory variables

\begin{tabular}{|c|c|}
\hline variables & Definition \\
\hline & Student Level Variables \\
\hline Age & Student age \\
\hline Fille & $\begin{array}{l}\text { Dummy variable ( } 1 \text { if the student is a girl and } 0 \text { if the student is a } \\
\text { boy) }\end{array}$ \\
\hline TRAVDOM & $\begin{array}{l}\text { This variable provides information on the domestic work done by } \\
\text { the student. Specifically, the question is whether the student does } \\
\text { housework on a regular basis. It is a dummy variable ( } 1=\text { yes and } \\
0=\text { no). }\end{array}$ \\
\hline MERALPHABET & Find out if the mother or guardian can read $(1=$ yes and $0=$ no) \\
\hline PERALPHABET & Find out if father/guardian can read $(1=$ yes and $0=$ no) \\
\hline AIDPARENT & $\begin{array}{l}\text { The student is helped in his homework by his parents ( } 1=\text { yes and } \\
0=\text { no) } \\
\text { School level variables }\end{array}$ \\
\hline MAITRFEM & Indicates whether the teacher is female ( $1=y e s, 0=$ no) \\
\hline MTAGE & Teacher's age \\
\hline MTCLASELEC & Identifies whether the classroom is electrified ( $1=$ yes and $0=$ no) \\
\hline LIVRCLASLFR & Pupil uses a reading book in class $(1=$ yes, $0=$ no $)$ \\
\hline DTSALLINFO & The school has a functional computer room $(1=$ yes, $0=$ no $)$ \\
\hline DTBIBLIO & The school has an equipped and functional library $(1=y e s, 0=$ no $)$ \\
\hline
\end{tabular}

Source: Author based on PASEC survey data.

The annex presents the results of the descriptive statistics of the variables. The results show that, on average, the students' score is 25.017 points. There is, however, a large disparity between individuals, with a standard deviation of 10.74 in the series. The difference between the maximum score (66.6 points) and the minimum score (1 point) shows the strong dispersion around the average. One of the quantitative variables is the age of the student and the teacher. According to the results, the average age of the students in the sample is 11 years. This average age is reasonable because the official age for enrolment in the first year of primary school is 6 years. At the level of teachers, the average age is 37 . 


\section{International Journal of Social Science and Economic Research}

ISSN: $2455-8834$

Volume: 05, Issue: 03 "March 2020"

The other explanatory variables used are qualitative. The results indicate that $44.28 \%$ of the students who answered the questions were girls, compared to $55.72 \%$ for boys. A considerable reduction in educational inequalities could be noted. However, while the gap between boys and girls in terms of access to classes is small, it is very high at the level of teachers. Among the teachers surveyed, $12 \%$ are women against $88 \%$ men. Analysis of the variable relating to classroom electrification reveals a critical state of access to electricity in the schools surveyed. Only $37.41 \%$ of the classes surveyed have electricity. The lack of electricity in classrooms undoubtedly limits the possibilities of installing certain work tools such as computer rooms and libraries. Indeed, the results show that among the schools in the sample, $2.90 \%$ have a computer room. The same is true for libraries, since more than $90 \%$ of the schools surveyed do not have an equipped and functional library. With regard to level 1 variables, we consider variables related to the family environment, such as parental education. The analyses show that $45.70 \%$ of the students state that they have mothers and guardians who can read and write. This proportion is higher $(71.36 \%)$ when it comes to the father's education.

\section{RESULTS AND DISCUSSIONS}

This section is devoted to the presentation and interpretation of the results of the estimation of the effect of electricity on educational attainment. To do so, we estimate a multilevel model comprising four equations. These four models are estimated by the restricted maximum likelihood method ${ }^{4}$. The results are reported in Table 2 below. First, we estimate an empty model. Model 1 is called an "empty model" because it contains no explanatory variables. This model makes it possible to examine the share of the intra-group variance and the inter-group variance in the total variance of the phenomenon under study. The expression for model 1 (empty model) is written:

$$
\text { Score_Elev } v_{i j}=\gamma_{00}+u_{0 j}+\varepsilon_{i j}
$$

From the estimation of the empty model, it is possible to calculate the inter-class correlation coefficient $(\rho)$ by the following formula:

$$
\rho=\frac{\sigma_{\text {inter-ecole }}^{2}}{\sigma_{\text {inter-ecole }}^{2}+\sigma_{\text {intra-ecole }}^{2}}
$$

Under these conditions $\rho$ indicates the share of the variance of student scores attributed to schools in relation to the total variance of student scores. The results of the model indicate that

${ }^{4}$ This estimator was preferred since some of the assumptions in the OLS are relaxed. 


$$
\rho=\frac{56.64005}{56.64005+59.76563}=0.486
$$

This result shows that $48.6 \%$ of the differences in performance between students are explained by differences between the sampled schools. There is then a significant difference in the final score of students from one school to another.

Table 2: Regression result

\begin{tabular}{|c|c|c|c|c|}
\hline Variables & Model 1 & Model 2 & Model 3 & Model 4 \\
\hline \multicolumn{5}{|l|}{ Fixed effects } \\
\hline \multirow[t]{2}{*}{ constant } & $24.9604 * * *$ & $25.9298 * * *$ & 25.8059 *** & $26.2588 * * *$ \\
\hline & $(0.000)$ & $(0.000)$ & $(0.000)$ & $(0.000)$ \\
\hline \multirow[t]{2}{*}{ TRAVDOM } & & $-1.2479 * * *$ & $-1.2988 * *$ & $-1.30 * *$ \\
\hline & & $(0.010)$ & $(0.017)$ & $(0.018)$ \\
\hline \multirow[t]{2}{*}{ AGE } & & & $-0.4115 * * *$ & $-0.4039 * * *$ \\
\hline & & & $(0.003)$ & $(0.003)$ \\
\hline \multirow[t]{2}{*}{ FILLE } & & & -0.618 & -0.6413 \\
\hline & & & $(0.126)$ & $(0.112)$ \\
\hline \multirow[t]{2}{*}{ PERALPHABET } & & & 0.4291 & 0.4674 \\
\hline & & & $(0.380)$ & $(0.339)$ \\
\hline MERALPHABE & & & $1.3403 * * *$ & $1.3050 * * *$ \\
\hline $\mathrm{T}$ & & & $(0.002)$ & $(0.003)$ \\
\hline \multirow[t]{2}{*}{ AIDPARENT } & & & 0.4955 & 0.4728 \\
\hline & & & $(0.342)$ & $(0.364)$ \\
\hline \multirow[t]{2}{*}{ MTCLASELEC } & & & $5.8686^{* * *}$ & $3.0650 * *$ \\
\hline & & & $(0.000)$ & $(0.052)$ \\
\hline \multirow[t]{2}{*}{ MTAGE } & & & 0.015 & 0.0227 \\
\hline & & & $(0.845)$ & $(0.761)$ \\
\hline \multirow[t]{2}{*}{ MAITRFEM } & & & $3.2737 *$ & $3.3115^{*}$ \\
\hline & & & $(0.070)$ & $(0.060)$ \\
\hline \multirow[t]{2}{*}{ DTBIBLIO } & & & 2.7998 & -3.7226 \\
\hline & & & $(0.178)$ & $(0.223)$ \\
\hline \multirow[t]{2}{*}{ DTSALLINFO } & & & 1.7583 & 2.5736 \\
\hline & & & $(0.620)$ & $(0.456)$ \\
\hline LIVRCLASLFR & & & $0.9537 *$ & 0.3292 \\
\hline
\end{tabular}


International Journal of Social Science and Economic Research

ISSN: 2455-8834

Volume: 05, Issue: 03 "March 2020"

$(0.057)$

(0.579)

Elect_Manuel

2.0532*

(0.060)

Biblio_Elcet

$11.5860^{* * *}$

(0.004)

Random effects

Level 2 :

(School) constant

variance slope

variance

$\begin{array}{ll}56.64005 & 56.930 \\ (7.25) & (7.28)\end{array}$

39.866

37.014 (5.63)

(29.88)

$2.506(3.24)$

$1.59(3.136)$

$1.05 \mathrm{e}-06(0.00)$

$1.13 \mathrm{e}-06$

$(0.00)$

Level 1 :

inter-student

variance

59.76563

(1.974)

14064.71

14081.48
59.508

(1.973)

13967.09

13989.42
58.549

12682.19

12775.5
58.3412

12668.14

12772.43

Source: Author based on PASEC data.

Note: ${ }^{* * *} P<0.01,{ }^{* *} p<0.05,{ }^{*} p<0.1$. Values in parentheses represent the critical probabilities associated with the significance test of the coefficients.

Model 2 introduces an explanatory variable for level 1 (student level). This refers to the domestic work done by the pupil in his or her home. The results show that this variable influences negatively and significantly at $1 \%$ the students' final score in the proficiency tests. The fact that a student regularly does housework leads to a 1.25 point drop in the final score. Indeed, by regularly doing housework, the student is allocated more time for these tasks, thus reducing the time spent on lesson review. Following the introduction of the level 1 variable, a change in the random part of the model is observed. The inter-class correlation coefficient $(\rho)$ is equal to 0.49 . It then emerges that almost half of the variations in pupils' final scores can be explained by both the pupil's school and domestic work.

Model 3 includes the Level 1 and Level 2 explanatory variables. It is a complete multilevel model. This model allows random variation in the regression slopes of the level 1 TRAVDOM 
International Journal of Social Science and Economic Research

ISSN: $2455-8834$

Volume: 05, Issue: 03 "March 2020"

and level 2 MTCLASELECT factors (Bressoux, 2010). By looking at the random part of the model, we see a decrease in the inter-class correlation coefficient. It amounts to $40.5 \%$. This decrease is caused by the introduction of the explanatory factor of level 2 (school level). Remember that the inter-class correlation coefficient is also a measure of the part of the variation that is unexplained and that can be explained by the pupil's school. So by adding an explanatory factor for the school level, a large part of the variation between schools is explained. As a result, the random constant varies less compared to previous models. Hence the decrease in the interclass correlation coefficient.

In the fixed part of the model, the results indicate a positive and significant $1 \%$ effect of classroom electrification on the final score of the pupils. The electrification of a classroom leads to a 5.9 point increase in the students' final score. This result can be justified by the fact that classroom lighting increases students' learning time. On the other hand, when the room is not electrified, it often limits teaching time. For example, in Côte d'Ivoire, especially during the rainy season, when the sky becomes threatening, classrooms without electricity are deprived of light. Thus, during this period, hours of teaching time are lost. Moreover, in the air of digital technology, electricity in a classroom encourages the use of new learning techniques, particularly through the use of new information and communication technologies (NICTs). This result is in line with those of Díaz (2015), Kuman and Rauniyar (2018), Mingaine (2013) and Faustino and Medina (2014). However, our result is contrary to that of Squires (2015). The latter showed that access to electricity reduces the level of education in a program of electricity expansion in Honduras. However, it should be noted that our variable to explain is different from that of Squires (2015).

In model 3, the domestic work variable still retains its sign and significance. The results show that the more the student performs housework on a regular basis, the final score on the proficiency test decreases by 1.3 points. The same is true for the student's age. Increasing the student's age by one year leads to a decrease in the final score of 0.41 points. This can be justified by repetition of previous classes. The advanced age in the primary cycle is very often linked to the repetition of classes by the pupil. Thus, the majority of these pupils are no longer motivated to complete the primary cycle. However, Michaelowa (2000) argues that all studies that find a negative effect of pupil age do so because they do not take into account repetition from previous grades.

With regard to parental literacy, a distinction is made between the literacy of the father and the mother. Naturally, one might expect a positive and significant effect of parental literacy on students' academic performance. Our results confirm this intuition. The MERALPHABET variable indicating the mother's literacy is statistically significant at the $1 \%$ threshold. This 


\section{International Journal of Social Science and Economic Research}

ISSN: $2455-8834$

Volume: 05, Issue: 03 "March 2020"

implies that when the student's mother is literate, this increases the student's score by 1.34 points. Unlike the mother's literacy, the PERALPHABET variable does not obtain a significant coefficient. Of course, in terms of comparison, one might expect a greater effect of the mother's literacy, since in Côte d'Ivoire, or even in Africa, it is the mother who generally spends more time with the children. This result contradicts that of Michaelowa (2000).

In his study on the determinants of educational quality, none of the variables relating to parental literacy, taken individually, were significant. However, Michaelowa (2000) indicates that the combination of the two variables is statistically significant. As might be expected, textbooks positively and significantly influence students' final scores at the $10 \%$ threshold. The use of a reading book increases student performance by 0.95 points. The gender of the teacher does not seem to play an important role in student learning. The coefficient associated with this variable is positive and significant at the $10 \%$ threshold.

In Model 4, we introduce interaction variables. Our variable of interest being electrification, it is the electrification that interacts with other variables. We have two interaction variables, namely the variable "Elect_Manual" which indicates that the student has textbooks and electricity available and the variable "Biblio_Elcet" which indicates the availability of an electrified library. The coefficients associated with these two variables are positive and significant at the threshold of $10 \%$ and $1 \%$ respectively. When a pupil has textbooks in an electrified classroom, this increases his performance in the proficiency test by 2.053 points. This effect is even greater for the variable "Biblio_Elcet". The coefficient associated with this variable is 11.586. This means that the fact that a school has a functional library and electrified classrooms increases the score of the students attending it by 11.59 points. Recall that taken individually, the variable relating to the presence of a functional library (DTBIBLIO) was insignificant. This result shows the capital importance of access to electricity in schools.

\section{CONCLUSION}

With all the investments made by Côte d'Ivoire in electricity infrastructure, it is important to consider the effects of access to electricity on the well-being of households. It is in this context that this study using PASEC survey data analysed the effect of classroom electrification on student performance. In the literature review, several methods of analysis are used to analyze the impact of electricity on education. The majority of these methods include randomized experiments (the double difference method or propensity scores) and ordinary least squares regression. In this research, the multi-level model was chosen since we have a hierarchical database. Moreover, this model allows us to take into account context effects. 


\section{International Journal of Social Science and Economic Research}

ISSN: $2455-8834$

Volume: 05, Issue: 03 "March 2020"

Many results have been obtained. First, from the estimation of the empty model, it appears that $48.6 \%$ of the differences in performance between students are explained by differences between the sampled schools. However, most of the differences are still attributable to Level 1 (student level) factors.

Second, the results show that among the student level factors considered, housework and student age have a negative and significant influence on student performance on proficiency tests. On the other hand, the mother's literacy skills increase the student's score by 1.34 points.

Finally, school-level factors play a crucial role in explaining school performance. This importance of school-related factors is justified by the significance of certain variables in models 3 and 4. The results show that electrification of a classroom leads to a 5.9 point increase in the students' final score. This result seems to corroborate the results found by previous studies (Díaz, 2015; Kuman and Rauniyar, 2018). The results also show that when a school has a library and electricity, it increases student performance by 11.59 points. Similarly, having textbooks in an electrified classroom increases student performance by 2.053 points. Thus, special attention should be paid to access to electricity in schools. The presence of electricity could improve pupils's performance who are subject to the double-shift system by increasing the learning time. Similarly, in rural areas, the electrification of schools could increase adult literacy.

\section{REFERENCES}

Aguirre, J. (2017). The Impact of Rural Electrification on Education: A case Study from Peru. The Lahore Journal of Economics, 91-108.

Barron, M., \& Torero, M. (2014). Ellectrification and Time Allocation: Experimental Evidence from Northern El Salvador. MPRA. Récupéré sur http://mpra.ub.unimuenchen.de/63782/

Bressoux, P. (2010). Modélisation Statistiques aplliquée aux sciences sociales (éd. 2e). de boeck.

Davies, G., Curries, C., \& Young, E. (2015). Impacts of Solar PV on Teacher Satisfaction. University of Strathclyde. Récupéré sur: https://www.dropbox.com/sh/m2wgfi7ev4wyet2/AAB5PZ9AX3dLPu7rZFIWIWK2a? $\mathrm{dl}=0$

Díaz, J. (2015). Energy and ICT for educational inclusion in Latin America in Heap. (i. Heap, Éd.) Smart Villages: New Thinking for Off-Grid Communities Worldwide Banson/Smart Villages Initiative.

DSPS. (2017). Statistiques scolaires de poche 2016-2017. DSPS. 
International Journal of Social Science and Economic Research

ISSN: $2455-8834$

Volume: 05, Issue: 03 "March 2020"

Faustino, N., \& Medina, M. (2014). Impact Evaluation of the School Electrificationn and Education (SEEd) Projevt of the Alliance for Mindanao Off grid Renewable Energy Program (AMORE): A Utilisation of Propensity Score Matching. Making IE Matters Conference', ADB Headquarters, Metromanila. Philippines. Récupéré sur t: http://www.3ieimpact.org/media/filer_public/2014/09/18/52impact_evaluation_of_the_sc hool_electrification_and_education_faustino_medina.pdf

Furukawa, C. (2013). Do Solar Lamps Help Children Study ?: Contrary Evidence from a Pilot Study in Uganda. Récupéré sur https://www.brown.edu/academics/economics/sites/brown.edu.academics.economics/files/ uploads

Givord, P., \& Guillerm, M. (2016). Méthodologie statistique: les Modèles multiniveaux. Institut National de la statistique et des Etudes Economiques.

IAE. (2017). Energy accees outlook. world Energy Outlook Special Report.

INS. (2015). Enquête sur le Niveau de Vie des Ménages en Côte d'Ivoire. INS.

Jimirez, A., \& Lawand, T. (2000). Revewable Energy for Rural Schools. National Renewable Energy Laboratory. Récupéré sur http://pdf.usaid.gov/pdf_docs/PNACK616.pdf

Khandker, S. R., Barnes, D. F., \& Samad, H. A. (2012). The welfare impacts of rural electrification in Bangladesh. The Energy Journal, 33(1), 187-206.

Khandker, S. R., Barnes, D. F., \& Samad, H. A. (2013). Welfare impacts of rural electrification: A panel data analysis from Vietnam. Economic Development and Cultural Change, 3(61), 659-692.

Kirubi, C., Jacobson, A., Kammen, D., \& Mills, A. (2009). Community- Based Electric MicroGrids Can Contribute to Rural Development: Evidence from Kenya. World Development, $37(7), 1208-1221$.

Kumar, S., \& Rauniyar, G. (2018). The impact of rural electrification on income and education: Evidence from Bhutan. Rev of Dev Econ. doi:10.1111/rode.12378

Maithani, P., \& Gupta, D. (2015). Achieving Universal Energy Access in India: Challenges and the way Forward. SAGE Publications India.

Michaelowa, K. (2000). Depenses d'éducation, Qualité de l'éducation et pauvreté: L'exemple de cinq pays d'Afrique francophone. $\mathrm{CD} / \mathrm{OCDE}$. 


\section{International Journal of Social Science and Economic Research}

ISSN: $2455-8834$

Volume: 05, Issue: 03 "March 2020"

Mingaine , L. (2013). Challenges in the Imple-mentation of ICT in Public Secondary Schools in Kenya. International Journal of Social Science and Education, 1(4), 224-238. Récupéré sur http://ijsse.com/sites/default/files/issues/2013/v4i1/paper/Paper-20.pdf

PASEC. (2012). Evaluation Diagnostique de l'école primaire: Pistes d'actions pour une amélioration de la qualité. CONFEMEN.

PNUD. (2012). Programme d'investissement pour l'accèss aux services énergetiques en Côte d'Ivoire. Côte d'Ivoire.

Provost, C. (2013). Energy poverty depries 1 billion of adequate healthcare, Says report. The guardian.

Squires, T. (2015). The Impact of access to Electricity on Education: Evidence from Honduras. Job Market Paper.

UNDESA. (2014). Electricity and education: The benefits, barriers, and recommendations for achieving the electrification of primary and secondary schools. Energy and Education.

UNESCO. (2016). L'éducation pour les peuples et la planète: Créer des avenirs durables à tous. UNESCO. Consulté le 03 08, 2017, sur www.unesco.org/gemreport

Van de Walle, D., Ravallion, M., Mendiratta, V., \& Koolwal , G. (2017). Lon-term gains from electrification in rural India. World Bank Economic Review, 31(2), 385-411.

Van de Walle, D., Ravallion, M., Mendiratta, V., \& Koolwal, G. (2013). Long-term Impacts of Household Electrification in rural India. World Bank Policy Research. Récupéré sur http://ideas.repec.org/p/wbk/wbrwps/6527.html.

YE, G. (2017). The impact of electricity access on education in Kenya. University of Illinois at Urbana-Champaign. 
International Journal of Social Science and Economic Research

ISSN: 2455-8834

Volume: 05, Issue: 03 "March 2020"

Appendix: Descriptive Statistics

\begin{tabular}{|c|c|c|c|c|c|c|}
\hline Variable & Definition & Obs & $\begin{array}{l}\text { Mean/ } \\
\text { proportion }\end{array}$ & Std. Dev. & Min & Max \\
\hline Score_Elev & $\begin{array}{l}\text { Pupil's Average } \\
\text { Score }\end{array}$ & 1975 & 25.017 & 10.745 & 1 & 66.6 \\
\hline TRAVDOM & $\begin{array}{l}1=\text { oui } \\
0=\text { non }\end{array}$ & $\begin{array}{l}1686 \\
426\end{array}$ & $\begin{array}{l}79.83 \% \\
20.17 \%\end{array}$ & 0.4013 & 0 & 1 \\
\hline AGE & Pupil's age & 2071 & 11.36 & 1.5974 & 7 & 18 \\
\hline PERALPHABET & $\begin{array}{l}1=\text { oui } \\
0=\text { non }\end{array}$ & $\begin{array}{l}1465 \\
588\end{array}$ & $\begin{array}{l}71.36 \% \\
28.64 \%\end{array}$ & 0.4521 & 0 & 1 \\
\hline MERALPHABET & $\begin{array}{l}1=\text { oui } \\
0=\text { non }\end{array}$ & $\begin{array}{l}952 \\
1131\end{array}$ & $\begin{array}{l}45.70 \% \\
54.30 \%\end{array}$ & 0.49827 & 0 & 1 \\
\hline AIDPARENT & $\begin{array}{l}1=\text { oui } \\
0=\text { non }\end{array}$ & $\begin{array}{c}365 \\
1760\end{array}$ & $\begin{array}{l}17.18 \% \\
82.82 \%\end{array}$ & 0.37726 & 0 & 1 \\
\hline FILLE & $\begin{array}{l}1=\text { girl } \\
0=\text { boy }\end{array}$ & $\begin{array}{l}941 \\
1184\end{array}$ & $\begin{array}{l}44.28 \% \\
55.72 \%\end{array}$ & 0.4968 & 0 & 1 \\
\hline MTCLASELEC & $\begin{array}{l}1=\text { oui } \\
0=\text { non }\end{array}$ & $\begin{array}{r}795 \\
1330\end{array}$ & $\begin{array}{l}37.41 \% \\
62.59 \%\end{array}$ & 0.4840 & 0 & 1 \\
\hline MAITRFEM & $\begin{array}{l}1=\text { Woman } \\
0=\text { Man }\end{array}$ & $\begin{array}{r}255 \\
1870\end{array}$ & $\begin{array}{l}12 \% \\
88 \%\end{array}$ & 0.3250 & 0 & 1 \\
\hline MTAGE & Teacher's age & 2099 & 37.0623 & 7.6251 & 23 & 55 \\
\hline DTBIBLIO & $\begin{array}{l}1=\text { oui } \\
0=\text { non }\end{array}$ & $\begin{array}{r}195 \\
1886\end{array}$ & $\begin{array}{l}9.37 \% \\
90.63 \%\end{array}$ & 0.2914 & 0 & 1 \\
\hline DTSALLINFO & $\begin{array}{l}1=\text { oui } \\
0=\text { non }\end{array}$ & $\begin{array}{c}60 \\
2006\end{array}$ & $\begin{array}{l}2.90 \% \\
97.10 \%\end{array}$ & 0.1679 & 0 & 1 \\
\hline LIVRCLASLFR & $\begin{array}{l}1=\text { oui } \\
0=\text { non }\end{array}$ & $\begin{array}{l}1617 \\
501\end{array}$ & $\begin{array}{l}76.35 \% \\
23.65 \%\end{array}$ & 0.4250 & 0 & 1 \\
\hline
\end{tabular}

